\title{
ETHOS PLATÔNICO E PAIDÉIA FILOSÓFICA
}

\author{
Evandson Paiva Ferreira*
}

\section{RESUMO}

Neste artigo, procuramos demonstrar como a questão da paidéia é colocada por Platão, na constituição de uma paidéia filosófica, como verdadeira educação. Para compreender sua originalidade, situamos o pensamento pedagógico de Platão no debate que realiza com a cultura de sua época, sobretudo com os sofistas - educadores que vendiam o seu conhecimento e viam na erudição a essência da paidéia.

PalaVras-ChaVEs: filosofia, educação, cultura, formação humana.

Platonic ethos and philosophical paideia

ABstract

In this paper I try to demonstrate how the Paideia issue is set by Plato in the constitution of a philosophic Paideia as the truly education. To understand its originality I situate Plato's pedagogical thought in the debate that develops with the culture of his time, with the sophists, educators that used to sell their knowledge and saw in erudition the essence of paideia.

KEY WORDS: philosophy, education, culture, human formation.

O problema da formação humana, pensado pelos gregos desde quando o mito era a principal referência simbólica dessa cultura e oferecia uma imagem de homem a ser imitada (educação homérica), ganha uma forma amadurecida entre os séculos V e IV a.C. É nesse período que as figuras de Sócrates e Platão colocam a questão da formação humana de uma maneira que marca, definitivamente, o debate em torno da educação.

Com Sócrates e Platão a filosofia, pela primeira vez, se lança no desafio de pensar a verdadeira educação, e assume para si a responsabilidade e o direito de decidir seus novos fundamentos. Para entender esse fenômeno na sua originalidade histórica, voltamos ao século V a.C., a Platão, cujos diálogos, nas palavras de Châtelet (1973, p. 65-66),

Professor Assistente de Filosofia no Cepae/UFG. E-mail: evandsonpaiva@ibest.com.br 
52 Revista Solta a Voz, v. 18, n. 1

não podem ser desligados do tempo que os viu nascer; a conjuntura histórica aqui é determinante. Destacá-los desse contexto estreitamente concreto, fazer deles uma das primeiras manifestações do espírito eterno, é condenar-se a nada compreender de sua originalidade e dessa forma que lhes permitiu atravessar a história.

No século V a.C. a Grécia cria e procura realizar um novo ideal político e educacional. Os primeiros filósofos são ainda sábios e não educadores. O pitagorismo é a primeira escola. Uma instituição com suas normas e sua sede, com reuniōes regulares, conforme uma confraria religiosa, em que seu mestre e discípulos se dedicam ao culto das Musas e de Pitágoras - seu fundador que depois de morto é heroificado. No entanto, como esclarece Marrou (1990, p. 83):

[...] não foi destes círculos de especialistas que emanou a grande revolução pedagógica com que a educação helênica daria um passo decisivo para a maturidade: ocorrendo na segunda etapa do quinto século, ela é obra deste pugilo de inovadores que se conveio em designar pelo nome de Sofistas.

O problema posto e resolvido pelos sofistas é o da formação do homem de ação. No século VI a.C., os gregos haviam feito a experiência da tirania que motivara, no século seguinte, a maioria das cidades, em especial a democrática Atenas, a se dedicar com vigor à vida política. Tal medida fez do exercício do poder e da gestão dos negócios públicos, o centro da nova areté que surgia e substituía a areté aristocrática, baseada na vida elegante, esportiva e luxuosa. Os sofistas se empenham neste novo ideal político: “[...] equipar o espírito do cidadão para a carreira de homem de Estado, formar a personalidade do futuro dirigente da cidade - tal o programa que eles concebem" (Marrou, 1990, p. 83). Pretendem ensinar a superioridade necessária a quem quer triunfar na política.

Desde o final do século XIX, historiadores da cultura grega e da filosofia têm se esforçado para resgatar a imagem dos fundadores da pedagogia democrática, os que primeiro se preocuparam em educar o cidadão da pólis democrática (Guthrie, 1995). O seu papel fora o de ensinar a arte da palavra necessária aos membros da democracia. Os sofistas representavam a possibilidade de outros grupos sociais dominarem as assembléias com o poder persuasivo da palavra. Não obstante sua importância na história da Grécia, a imagem que ficou dos sofistas foi a fornecida por Platão. Este, 
não foi o único a tecer críticas à prática deles. Sócrates, ao lado dos aristocráticos - que viam na condição de cidadão algo inato, parte intrínseca da natureza, que não pode ser ensinada a qualquer pessoa -, também levantou comentários desfavoráveis aos sofistas. Mas foi, sem dúvida, a crítica platônica a mais marcante e que deixou para a posteridade a associação do sofista com o mercenário que vende o saber em troca de algum dinheiro.

$\mathrm{O}$ intuito do ensino sofístico consistia em formar a personalidade do indivíduo para este se destacar como líder na cidade. Ademais, almejavam fazer dos alunos bons cidadãos, aptos a conduzirem com sucesso sua casa e os negócios do Estado. O primeiro aspecto dessa formação fundamenta-se em ensinar o aluno a vencer qualquer discussão. $\mathrm{Na}$ arte retórica, os sofistas foram os grandes mestres, mostraram com habilidade que num assunto qualquer é possível sustentar opiniōes diversas. Protágoras foi o primeiro a afirmar que toda questão pode ser mantida, por meio de argumentos, sejam estes a favor, ou contra. Em vez do raciocínio, que garantiria a consistência lógica dos argumentos, são apresentados audaciosos paralogismos, que acabam persuadindo o público dos sofistas, formado por jovens ainda ingênuos. Ao lado da arte de persuadir, os sofistas se ocuparam em ensinar a arte de falar. $\mathrm{Na}$ Grécia, a palavra falada é mais importante que a palavra escrita.

É em oposição à educação pragmática dos sofistas que vemos surgir a figura emblemática de Sócrates. Para este, o grande erro dos sofistas era girar seu ensino em torno do senso comum, com o aspecto imediato da vida política, sem sujeitá-la ao tribunal da theoría. Mas os sofistas são um produto de sua época. A Atenas de Sócrates não é dada ao pensamento especulativo. Os filósofos são vistos com desconfiança, acusados de colocarem em dúvida os valores tradicionais. É nessa cultura que Sócrates começa a desenvolver um novo jeito de filosofar.

Com os sofistas e com Sócrates a discussão intelectual passa do interesse no mundo físico - objeto de reflexão dos primeiros filósofos, os chamados pré-socráticos-, ao interesse na esfera da ética e da política. Antes de Aristóteles instituir a ética como ciência do ethos, Sócrates inaugura a reflexão em torno da moral. Filosofa na rua, com seus concidadãos, em lugares freqüentados por todos, e tem nos sofistas seus principais interlocutores. A reflexão iniciada por ele chega ao amadurecimento pelas mãos de seu discípulo Platão. Desse modo, podemos dizer que aquele será entendido, então, como uma voz deste. Sócrates nada escreveu e tudo o que dele 
sabemos se deve aos seus discípulos, sobretudo Platão e Xenofonte - neste trabalho privilegiamos o texto do primeiro. Portanto, há certa dificuldade em estabelecer o que é o pensamento de Sócrates na obra de Platão. A esse respeito, Reale explica que:

Platão põe na boca de Sócrates quase toda a própria doutrina: a da sua juventude, a da própria maturidade e parte da doutrina da velhice (Filebo), e é certo que, na maior parte, estas doutrinas não são de Sócrates, mas repensamentos, ampliaçōes e também novas criações de Platão. Como separar o que é socrático do que é platônico nos escritos platônicos? Existe algum critério para fazer isto? A resposta é que a separação é, se não de todo impossível, pelo menos dificilíssima, porque tal critério não existe, ou, se existe um critério, este é apenas muito aproximativo, porque Platão, a partir do momento em que se põe a escrever, não transcreve objetivamente, mas interpreta, repensa, revive, explicita, aprofunda, constrói sobre, transpōe: em suma, em Sócrates ele projeta a si próprio, totalmente (Reale, 1993a, p. 249-250, grifo do autor).

O confronto entre a paidéia sofística e a paidéia platônica, conforme aparece nas obras de Platão, é, na verdade, o confronto entre dois ethos, o sofístico e o platônico. Estes representam dois modos de compreender o homem e a sociedade, dois mundos antagônicos que lutam pela hegemonia na educação. $\mathrm{O}$ Protágoras pode ser apontado como a primeira obra em que este duelo é exposto com maior clareza. Embora na Apologia, Sócrates seja apresentado como educador, é no Protágoras que a paidéia filosófica expõe seus contornos amadurecidos e em oposição à paidéia sofística (Platão, 1997). O educador sofista é descrito como mercador e vendedor ambulante que oferece, por dinheiro, as mercadorias, ou seja, o seu conhecimento. A idéia de bagagem intelectual teve aqui a sua primeira problematização:

[...] o sofista, que instila no espírito humano, ao sabor da intuição, toda a sorte de conhecimentos, representando por isso o tipo de educação standard de todos os tempos, até dos atuais, e Sócrates, médico das almas, para quem o saber é o alimento do espírito e que se preocupa sobretudo com saber o que lhe será proveitoso ou prejudicial (Jaeger, 2001, p. 624, grifos do autor).

O Górgias é outra obra platônica que tem como questão o debate sobre a retórica. A discussão propicia o confronto entre duas concepçôes 
antropológicas, duas formas de vida. Uma se submete ao desejo (epitimía) e ao descomedimento (pleonexía), a outra é guiada pelo saber verdadeiro (epistéme) e, por conseguinte, pela medida (métron) e pela ordem (táxis).

Górgias, o personagem que dá nome ao diálogo, é um sofista que se propõe a formar oradores, pois num regime democrático o estadista precisa ser orador. "Nos debates travados na assembléia do povo ou em qualquer outra assembléia de massas, para escolher a quem se dará a direção de determinado cargo, não será o perito, mas sim o retórico, quem se imporá", explica Jaeger (2001, p. 650-651). Naquele tempo, estadista e retórico eram sinônimos. Daí podemos entender, segundo Platão (1975), no Fedro a incorporação, por parte de Platão, da retórica na sua paidéia, conforme exporemos neste artigo. É esse o ponto de partida para Sócrates debater.

Eis como Górgias fala do poder de persuasão do retórico:

se um orador e um médico se apresentarem numa cidade qualquer à tua escolha e se discutir na assembléia do povo ou em qualquer reunião qual dos dois deve ser eleito médico, garanto-te que o médico deixa simplesmente de existir e que aquele que domina a arte da palavra se fará eleger, se quiser.

Do mesmo modo, seja qual for o profissional com que entre em competição, o orador conseguirá que o prefiram a qualquer outro, porque não há matéria sobre a qual um orador não fale, diante da multidão, de maneira mais persuasiva do que qualquer profissional. Tal é qualidade e a força desta arte que é retórica (Platão, Górgias, 456 b-c).

Outro personagem do diálogo que, com Górgias, representa o ethos sofístico é Pólo. Para este, a retórica é indiferente às questōes morais. A moral da sociedade é entendida como uma questão puramente convencional. Platão põe lado a lado duas gerações de sofistas: de um lado um sofista da velha geração, tingida de moral e, de outro, a nova geração, amoral. No meio deles Sócrates desenvolve dialeticamente a questão, revelando a verdadeira essência da retórica.

$\mathrm{Na}$ segunda parte do diálogo, a discussão gira em torno de ser, ou não, a retórica uma arte, uma tékne. Para Sócrates, ela não é uma verdadeira tékne. Segundo ele, para tal é preciso apresentar algumas características. A tékne é um saber que se baseia no conhecimento da verdadeira natureza do seu objeto, capaz de dar conta de suas atividades uma vez que conhece suas razóes. 
Ao comparar a retórica às "artes" menos nobres, Platão quer mostrar a verdadeira face da retórica dos sofistas e, com isto, desmontar o humanismo destes que, segundo ele, agem como se pudessem fazer dos seus semelhantes o que bem entendessem. Vemos, assim, duas concepções de mundo, de homem e de natureza humana diametralmente opostas: a filosofia do poder - a retórica -, em confronto com a filosofia da educação - da paidéia, da busca da excelência nos planos pessoal, coletivo e político. A primeira baseada na violência, cujo sentido e razão de ser não é mais que a obtenção do máximo poder que possa ser alcançado. A segunda, aponta ao homem outro objetivo, o sentido ético, de construção do ethos, da morada humana do verdadeiro homem. "É assim que eu vejo as coisas", diz Sócrates a Pólo, "o homem e a mulher são felizes quando são bons e virtuosos, infelizes quando são injustos e maus" (Platão, Górgias, 470 e).

É a paidéia, e não a violência, que constitui o verdadeiro sentido da natureza humana em Platão. Não é algo oposto à natureza humana, mas o seu realizar-se. Está aqui o fundamento da crítica à antropologia sofista. Platão não condena o poder, mas o interroga criticamente. $O$ poder tem de constituir um bem real, de modo que o homem aspire por ele. Agir conforme cada um acha que é melhor, não é nenhum bem, quer seja um tirano ou retórico que o faça, uma vez que não se baseia na razão.

No diálogo com Pólo, Platão mostra que, apesar de sua formação retórica, esse sofista fracassara na discussão dialética. A retórica, habituada a ganhar multidões graças ao pouco esforço do pensamento, não resiste ao ataque da arte socrática - a dialética. Desse modo, é revelada como um saber vazio, sem conteúdo.

A aparição, no diálogo, do estadista Cálicles - o mais coerente representante do "homem retórico" - é a última tentativa de Platão para salvar a retórica. Cálicles é a personificação da hostilidade contra a filosofia e seu espírito especulativo, do conflito entre o homem de ação e o homem de pensamento. Esboça uma doutrina da sociedade baseada no direito do mais forte, conferindo à paidéia um papel inferior. Ele ainda a reduz a mero adestramento que prejudica as naturezas fortes e mantém de pé o poder dos fracos. O ponto central de sua fala é a crítica voraz contra os que praticam a especulação filosófica.

Esta é a verdade e tu reconhecê-la-ás se puseres imediatamente de parte a filosofia para te dedicares a assuntos mais altos. A filosofia, Sócrates, não 
deixa, de facto, de ter o seu interesse, quando é estudada com moderação na juventude, mas, se se prolonga o seu estudo para além do conveniente, transforma-se numa autêntica calamidade. Por mais bem dotado que um homem seja, se se entrega à filosofia até uma idade avançada, perde necessariamente o contacto com todas aquelas realidades cuja experiência é indispensável a quem pretenda ser uma pessoa educada e digna de consideração (Platão, Górgias, 484 c-d).

Cálicles termina sua longa fala aconselhando Sócrates a deixar a filosofia, uma vez que ela destrói os grandes dotes de seu espírito. $\mathrm{O}$ estadista procura demonstrar sua erudição por meio de citações poéticas de Eurípedes e Píndaro.

Acredita-me, meu caro, deixa-te de argumentações, "cultiva a arte dos negócios", exercita-te naquilo que te pode dar a reputação de homem sensato, "deixando aos outros todas essas subtilezas", que não passam de tolices ou frivolidades e que "acabarão por te fazer habitar uma casa vazia"; toma por modelos, não esses argumentadores de bagatelas, mas os homens que souberam adquirir riquezas, glória e os outros bens da vida (Platão, Górgias, $486 \mathrm{c}-\mathrm{d})$.

A última tentativa para salvar a retórica, Cálicles a faz retomando a eloqüência dos grandes estadistas atenienses do passado - Temístocles, Címom, Milcíades, Péricles - como modelo da arte de educar. Platão faz uma apreciação crítica da política deles. Se o que faz grande um estadista é a satisfação dos seus próprios interesses e os da massa, esses estadistas são conforme os descrevem a história. No entanto, se ao estadista cabe a missão de conferir às suas obras uma idéia de perfeição para que se orientem por essa mesma idéia, como o que faz o pintor, o arquiteto, o construtor naval e qualquer outro técnico, que ordena de modo lógico as partes do todo, ajustando-as bem, tais estadistas do passado não foram mais que uns incompetentes. Afirmações duras, que traz no Górgias a primeira revelação completa do programa da paidéia platônica, na sua referência ética e metafísica.

O conceito que Cálicles tem da natureza humana funda-se na equiparação do bom ao agradável, ao que dá prazer. Sócrates assume tal questão como premissa para o desdobramento do diálogo. Para Cálicles, o mais forte é o mais sábio no campo da política e, o mais viril, aquele cuja alma 
não se encontra amolecida e que domina. $\mathrm{O}$ problema que vem a seguir é saber se quem nasceu para dominar deve também dominar a si próprio. Sócrates defende que sim, enquanto Cálicles defende um ideal de liberdade que consiste em fazer o que se deseja.

Assim, o diálogo chega num ponto em que se deve discutir o melhor tipo de vida. Vemos, então, em conflito, mais uma vez, o ethos de Sócrates e o dos sofistas. Sócrates recorre a imagens religiosas para simbolizar o homem insaciável de prazer, cuja vida "seria uma coisa terrível" (Platão, 2000b, 492 e). Para Cálicles, uma vida sem prazer é a vida de uma pedra ou dos mortos. Não há da parte de Platão um desprezo pelo prazer. O que faz, por meio de Sócrates, é levar seu interlocutor a uma distinção entre sensações agradáveis, boas e más. Daí “é elaborado o conceito de opção da vontade e do objetivo final desta, como tal se apresentando o bem" (Jaeger, 2001, p. 673).

A conversa com Cálicles, que começou sobre o direito do mais forte, é conduzida a um ponto bem diferente do de partida. O prazer e o desprazer, conforme os argumentos de Sócrates, não podem servir de medida à conduta do homem. Também a retórica deve renunciar à lisonja das multidōes. A procura do agradável por causa do bem é a missão que não cabe a qualquer um, pois exige um saber, uma competência especial. No início do diálogo, Sócrates pergunta sobre o saber da retórica e conclui que ela não tem um saber. Para ele, ela não é mais que um meio de manipular as massas com palavras vazias.

A interrogação inicial sobre a melhor forma de vida ganha significado. São distinguidos dois tipos de vida. O do retórico, que visa ao prazer do aplauso e, o do filósofo, que busca o conhecimento da natureza do homem. Só a filosofia, e a paidéia que nela se inspira, pode ser tékne, pois é teleológica, sabe o seu fim, e seu discurso é uma terapêutica da verdade. Cálicles, que no início da sua intervenção aparece com personalidade forte e imponente, no decorrer do diálogo vai sendo revelado como fraco, como alguém que, para dominar, precisa se adaptar exteriormente. Ou melhor, não é a pessoa de Cálicles que é fraca, mas o seu pensamento.

No tempo de Platão, conforme já foi mencionado, retórico e estadista são sinônimos, e no Górgias Sócrates é apresentado como o único que cultiva a verdadeira política. Somente no Fedro há uma mudança na forma de Platão julgar a retórica, quando assimila à sua paidéia a verdadeira retórica. Essa mudança reforça o que já esboçava no Górgias sobre a relação 
do estadista e do conhecimento da verdade. No Fedro, Platão afirma que a retórica só é arte se se apoiar na epistéme (Platão, 1975). O pensamento político e pedagógico tem contornos mais definidos na República e nas Leis. O verdadeiro estadista e orador deve conhecer a justiça, pois o conhecimento impede a prática do mal. Ninguém pratica voluntariamente o mal, sendo este o fruto da ignorância.

Se no Protágoras e no Górgias, Platão coloca as novas bases de sua paidéia, no Mênon ele situa o novo conceito de saber, em oposição à concepção mecânica do que é aprender na paidéia sofística. Aprender não consiste em assimilar passivamente conhecimentos, mas uma procura laboriosa por parte daquele que se dispõe espontaneamente a aprender.

O Mênon investiga o problema do saber e das suas origens. O diálogo começa com a indagação da possibilidade de a virtude ser ensinada. Se esta surge pelo exercício, ou aparece por natureza. Ao contrário dos sofistas que, por ofício, têm sempre uma resposta imediata a todas as questôes - e graças a esse imediatismo são considerados convincentes -, Sócrates descarta a pergunta de Mênon: "Aquilo que eu não sei o que é, como hei-de saber de que qualidade é?" (Platão, Mênon, 71b). Mas o aparente descarte de Sócrates não é mais do que o início da problematização da questão, de modo a revelar novos ângulos para quem pergunta. Mênon se espanta com a resposta de Sócrates, ao que este diz nunca ter encontrado alguém que soubesse dizer com clareza se a virtude é ensinável. Mênon não é um dos sofistas. Mas como alguém que teve uma convivência com eles, aparece no diálogo com traços sofísticos. O indício mais evidente disto é a sua pressa em responder às provocaçôes de Sócrates, sem o cuidado necessário em medir suas posições.

Aprofundando a questão, Sócrates quer saber de Mênon o que ele entende por virtude. Na primeira resposta, Mênon se refere à virtude de um homem, em seguida, à de uma mulher, dos filhos, concluindo que cada um tem a sua. No entanto, Sócrates quer saber o que é a virtude, para além da multiplicidade das virtudes empíricas. Com um exemplo quer fazer Mênon perceber a distinção entre o múltiplo e o uno.

Olha! E o tamanho e a força? Se uma mulher for forte, será pelo próprio aspecto ou pela própria força? Com efeito, relativamente à expressão "pela própria força", pretendo dizer isto: "não há diferença nenhuma quanto ao facto de a força ser força, quer esteja no homem, quer esteja na mulher" (Platão, Mênon, 72 e). 
Mênon concorda com Sócrates e lhe dá uma segunda resposta a fim de tentar explicar a virtude em geral: "Que coisa é ela senão ser capaz de comandar homens?" (Platão, Mênon, 73 d). Sócrates acrescenta "justamente ou injustamente". Mênon pensa que a justiça é virtude. Sócrates rebate: "a virtude ou uma virtude?" (Platão, Mênon, 73 e). Com os exemplos da figura, que embora apresentem muitas formas continua sendo figura, $\mathrm{e}$ da cor, que segue o mesmo raciocínio da primeira analogia, Sócrates quer levar Mênon a ver a "mesma coisa em tudo", indo do múltiplo ao eidos.

Ao tentar uma terceira explicação, Mênon diz que virtude é ter poder de alcançar coisas boas. Sócrates aprofunda a reflexão. $\mathrm{O}$ que são as coisas boas? Para Mênon, adquirir ouro e prata, honras e cargos na cidade são as coisas boas. Sócrates propõe acrescentar ao adquirir as palavras "justa e piedosamente". A renúncia a todas essas coisas boas, se sua aquisição não tiver sido justa, também é virtude.

Diante da ignorância de Mênon quanto à virtude, uma vez que descobriu não saber o que ela é, Sócrates propõe examinar o que ela significa. Mas como investigar aquilo que se ignora o que é? A essa interrogação, Sócrates começa expor sua teoria do conhecimento. Se do desconhecido não há saber, Sócrates procura na teoria da reminiscência a origem das idéias. A alma sendo imortal, já teria aprendido tudo no além. Aprender é recordar. É a primeira resposta dada ao problema do conhecimento que procura superar a aporia erística, a qual sustentava que a pesquisa e o conhecimento são impossíveis. Essa recordação é apresentada sob duas maneiras: uma mítica e outra dialética. A primeira inspira-se em doutrinas religiosas órfico-pitagóricas que se referem à imortalidade da alma. Mas no diálogo de Sócrates com o escravo de Mênon, Platão vai além do mito, colocando a maiêutica, argumentando racionalmente acerca de uma questão de geometria. Esse recordar é um trabalho ativo de quem quer conhecer. "longe de ser um mito, é uma constatação e uma prova de fato, ou seja, que o escravo, como todo homem em geral, pode tirar e extrair de si mesmo a verdade que antes não conhecia e que ninguém lhe tinha ensinado" (Reale, 1993b, p. 155, grifos do autor).

Após dialogar com o escravo e convencer Mênon de sua teoria do conhecimento, Sócrates volta à questão da virtude levantando duas possibilidades: se a virtude for saber é passível de ser ensinada, do contrário não. Se ela for considerada como saber, é preciso que haja professores nessa matéria, e Sócrates não os vê: "Apesar de andar muitas vezes a investigar se 
há alguns professores desta ciência e apesar de fazer todos os esforços, não consigo encontrá-los!" (Platão, Mênon, 89 e). Nesse momento do diálogo aparece Ânito para participar da discussão dessa hipótese. Ao argumentar que quem quiser exercer determinado ofício deve ser enviado a professores que o dominem e que quem quiser receber liçōes de virtude deve ser enviado aos sofistas, Sócrates provoca em Ânito furor e repulsa contra tais professores. Este diz não ter tido qualquer lição de nenhum deles. Da participação de Ânito na conversa surge uma nova questão: se os sofistas, os que se dizem professores de virtude, não o são, mas se há homens virtuosos, quem os fez assim?

Essa questão será respondida por Sócrates na retomada do diálogo. É verdade que existem homens bons, mas eles não se apresentam como professores de virtude, embora alguns deles defendessem que a virtude é ensinável. Se a areté dos homens justos fosse um saber, eles teriam educado outros nesse saber. Sócrates faz a distinção entre opinião verdadeira e saber. A existência de homens sábios se explica pela opinião verdadeira, pessoas que vivem com sensatez, mas sem o conhecimento verdadeiro da virtude. Só o saber conduz ao agir reto, embora a opinião verdadeira produza o mesmo efeito. Completa Mênon: "Ó Sócrates, somente há uma diferença: é que aquele que possui o saber sempre poderá alcançar a sua meta e o que possui a opinião recta, muitas vezes, poderá alcançá-la, outras, não" (Platão, Mênon, 97 c). A opiniāo mesmo sendo reta (orthé dóxa) é lábil, suscetível ao erro, enquanto a epistéme, o saber, é salvaguardado pela razão (Vaz, 1997, p. 13, nota 22). O bom senso que marca a ação de alguns governantes, se não é fruto do saber (epistéme), explica Sócrates, deve ser inspirado pelo espírito da divindade.

A República, obra da maturidade, escrita em 375 ou 374 a.C., traz em si uma reunião de questôes já discutidas em textos anteriores e abre novas discussões que serão amadurecidas mais tarde. Síntese do passado e do futuro, A República ocupa uma posição central no conjunto da obra de Platão. Além disso, dá oportunidade ao leitor de apreciar, com detalhada descrição, a paidéia platônica, pensada na conjunção da teoria política e da teoria do conhecimento. Estas não se separam e visam à construção da cidade ética e, por conseguinte, a paidéia do verdadeiro homem que emerge de dentro do próprio homem. Ao dar um novo sentido para o Estado, Platão coloca a politéia e a paidéia numa relação intrínseca, em que a perfeição da primeira depende da excelência da segunda. A paidéia é a 
essência do Estado platônico. Não é possível compreender o pensamento político de Platão sem, ao mesmo tempo, compreender o tipo de homem que a paidéia quer formar.

Depois da rápida aparição de Trasímaco no Livro I, defendendo a justiça como poder do mais forte, questão já presente em outros escritos platônicos, a partir do Livro II a questão da justiça, da vida ética, da pólis ideal e da paidéia como responsável fundamental pelo Estado, ganha corpo na discussão de Sócrates e seus interlocutores, Glauco e Adimanto. O debate com Trasímaco "não passara de simples proêmio" (A República II, 357 a).

Glauco expõe três questões que dizem respeito à justiça e que serão analisadas por Sócrates. A primeira diz respeito ao que, na opinião geral, é a justiça. A segunda, consiste em mostrar "como todas as pessoas que a praticam o fazem a contragosto e por obrigação, como se não se tratasse de algum bem, mas de um mal necessário" (A República II, 358 c). E a terceira, "que essas pessoas se comportam com coerência, pois é muito melhor, segundo dizem, a vida do homem injusto do que a do justo" (A República II, 358 c). A fala de Glauco e de Adimanto não tem por objetivo convencer Sócrates, mas fornecer elementos para sua reflexão. Na argumentação de ambos, a injustiça aparece como mais sedutora e cômoda que a justiça. Cabe a Sócrates mostrar que a justiça é o bem a que todo homem deve almejar.

Ao desafio proposto pelos dois irmãos, a primeira reação de Sócrates é a de humildade frente à dificuldade em discorrer sobre tão relevante assunto, mas com coragem assume o desafio. Tal estudo, segundo Sócrates, exige vista penetrante, o que o leva a ampliar a discussão, passando da justiça do indivíduo para a cidade, uma vez que nessa é mais fácil de conhecê-la, para em seguida retornar ao indivíduo. Essa proeminência da cidade em relação ao indivíduo soa estranha ao homem moderno, que tem no individualismo um distintivo de Modernidade. Ao contrário, para o espírito grego, a cidade vem antes do homem.

Sócrates descreve todo processo de constituição de uma cidade, suas categorias profissionais, necessidades básicas de sobrevivência, comércio, agricultura. $\mathrm{Na}$ descrição de sua cidade, chega à figura do guardião, aquele que é responsável pela defesa da pólis. Aqui começa a ganhar luz a questão da paidéia e a formação do verdadeiro homem. Começando pela formação dos guardas, compara a natureza destes à natureza de um cachorro de boa raça. Imagem grosseira, mas forte, que diz bem o que Sócrates espera desse guardião: forte para perseguir e lutar contra o inimigo. $\mathrm{O}$ 
guardião dessa pólis fará distinção entre os amigos e os inimigos, tendo, portanto, natureza filosófica. Platão começa, então, a descrever o filósofo como modelo ético dessa nova paidéia.

Perante a questão - de que maneira tais guardiōes serão educados? -, abre-se o véu, revelando Sócrates, a essência da paidéia filosófica que se fundamenta num ethos oposto à opiniāo corrente e que lança bases para uma verdadeira civilização da razão. $\mathrm{O}$ ponto culminante dessa paidéia é o paradoxo de propor o governo do filósofo como única salvação para o Estado. Platão une, dessa maneira, a filosofia e o poder político. Somente afastando os que se dedicam a essas atividades, filosofia e política, em separado, como se nada tivessem entre si, cessarão os males da cidade. Ao colocar nas mãos do filósofo o papel de dirigente dessa politéia, Platão faz dele o centro e o modelo de sua paidéia. Na República faz um minucioso relato do amante da sabedoria (philósophos) em oposição ao amante da opinião (philódoxos), distinguindo entre epistéme, que alcança o ser, e dóxa, intermediário entre o ser e o não-ser, conhecimento verdadeiro e opinião. Conforme afirma Platão (A República V, 478 d): "Assim, opinião viria a constituir um meio termo entre ambos". A distinção entre dóxa e epistéme e a descrição do perfil do filósofo são um passo definitivo para além do estágio da "opinião reta" do Mênon.

O filósofo, na concepção de Sócrates, ama a verdade e nunca admite conscientemente a mentira. Esse amor à verdade fora explorado pela primeira vez em $O$ banquete. Nesse diálogo, a filosofia é apresentada em íntima ligação com Eros. Reunidos na casa de Agatão, Sócrates e seus amigos se dispōem a falar sobre o Eros. A fala de Sócrates sobre o amor toma como base os ensinamentos recebidos de Diotima, uma sacerdotisa -personagem sugerida por Sócrates, a qual não faz parte do banquete, mas que passa a ter o lugar central ao narrar o nascimento de Eros.

Assim como Eros está entre carência e recurso, também está a filosofia em relação à sabedoria e à ignorância. Não possuindo o saber, o filósofo a esse aspira e, à medida que o procura, ele lhe escapa. Cabe ao filósofo buscá-lo mais além. Nesse sentido, quando pensamos educação, o mais importante não é chegar à verdade, mas colocar-se a caminho dela. Isso implica resistir à tentação de descansar na ilusão da posse da verdade atingida (Teixeira, 1999, p. 99).

Platão tem um especial cuidado com a formação do verdadeiro filósofo, de modo que não se aproximem da filosofia indivíduos sem vocação 
e que fazem tanto mal ao exercício do filosofar. Além disso, a filosofia é um ofício para pessoas mais velhas, maduras, que saberão lidar com maior responsabilidade com a dialética.

Embora reconhecendo que em todos os outros livros de A Repúbli$c a$, Platão oferece elementos que dão uma nova forma de entender a educação, ele apresenta elementos morais que vão de encontro à moral grega de sua época. O interesse desse estudo é apontar os fundamentos essenciais de sua paidéia, presentes sobretudo no Livro VII. Vemos esse livro sob duas perspectivas: como ponto de chegada e de partida. Ponto de chegada a que o leitor é conduzido pela dialética socrático-platônica e ponto de partida para a nova paidéia que visa formar o verdadeiro homem convertido pela verdade (alétheia).

A alegoria da caverna é a imagem usada por Sócrates para representar a nova paidéia. Ele descreve homens que vivem numa morada subterrânea, um ethos inferior, no fundo de uma caverna, que contém uma única entrada com vista para a luz em toda a sua largura. Estão lá desde pequenos, com pernas e pescoço presos de tal modo que só podem olhar para frente. Um fogo brilha no alto e por trás desses homens. Entre eles e o fogo há um caminho que passa por cima, ao longo do qual há um muro. Por detrás deste muro, homens carregam objetos que são mais altos que o muro. Estes carregadores conversam entre si. Os homens acorrentados só conseguem ver sombras, as quais pensam ser os próprios objetos, e as vozes dos carregadores, as vozes de tais objetos.

Sócrates considera, então, o que aconteceria se um dos homens acorrentados se libertasse, dirigindo-se e olhando rumo à luz, "não apenas tudo isso lhe causaria dor, como também o deslumbramento o impediria de ver os objetos cujas sombras até então ele enxergava” (A República VII, 515 d). Um interlocutor mostraria os objetos dos quais ele só via as sombras. Ao ser forçado a olhar para a luz, sentiria dor nos olhos. À luz do sol ficaria com a vista ofuscada. Por meio do raciocínio descobriria que o sol é a causa das estações do ano e tudo dirige no espaço visível. Este homem, quando se lembrasse de sua situação anterior e a de seus companheiros de prisão, se felicitaria pela mudança de sua condição e lamentaria a sorte dos outros que ficaram presos.

E se esse indivíduo tivesse que voltar à caverna, como seria? Ele se tornaria objeto de galhofa. Para os outros, o passeio lá em cima estragara sua vista. Caso ele tentasse libertá-los e conduzi-los para fora da caverna, ao mundo superior, talvez fosse morto pelos outros. 
Essa saída da caverna, que a paidéia filosófica proporciona àquele que a ela se submete, não é apenas um conhecer novas paisagens. $\mathrm{O}$ importante para quem faz esta experiência é que o lugar em que anteriormente vivia apareça como completamente outro. Ao voltar, o prisioneiro que se libertou, não será mais o mesmo. Libertou-se das antigas convicções e preconceitos. Olhará para as sombras e se admirará como pôde pensar ser aquilo a realidade. Não será reconhecido pelos outros, uma vez que estes ainda estão presos. Essa nova paidéia não aumenta a bagagem de conhecimentos de quem a vive, mas apenas o ensina a ver diferente, a pensar livremente, uma vez que conhece a verdade.

A paidéia tradicional grega, fundamentada na ginástica e na música, não é mais suficiente, diante dessa nova realidade. Uma educação que propõe apurar a capacidade visual, de modo que o educando tenha vista penetrante, exige estudos que conduzam do múltiplo ao uno, à verdadeira ciência. Assim, Sócrates chega aos novos elementos dessa paidéia: o cálculo e a aritmética.

O cálculo e a aritmética têm uma importância prática ao guerreiro para distribuir suas tropas. Mas não é só esse lado que Sócrates vê. O cálculo e a aritmética tratam de conhecimentos que escapam ao materialmente dado, são abstrações. Emergem "do mar dos fenômenos transitórios" e atingem "a essência" (A República VII, 525 b). Obrigam a alma a recorrer à inteligência para alcançar a verdade em si.

À aritmética, Sócrates acrescenta a geometria plana, pois esta também tem a propriedade de arrastar a alma para a verdade, formando o espírito filosófico. Acrescenta também a geometria espacial (estereometria), conhecimento novo para sua época (Soares, 2002, p. 52), e ainda a astronomia, que força todos a olharem para cima, não com os olhos, mas com o pensamento. Também a música, não no seu ensino puro, mas a teoria musical.

Sócrates expõe como seria a formação de acordo com as idades. A educação espiritual começa desde a mais tenra idade, despertando na criança o prazer pelo estudo, no seu caráter lúdico. Dos dezessete aos vinte anos teria a educação gímnica, período em que a educação espiritual seria suspensa, uma vez que a fadiga e o cansaço não dão ânimo ao estudo. Aos vinte anos, depois de dois ou três anos dedicados à ginástica, entra em contato novamente com os conhecimentos que lhe foram ensinados na infância, só que sob forma sinótica, isto é, dar uma visão de conjunto do já 
conhecido. Aqueles que conseguirem ter essa visão conjunta, percebendo a relação entre os vários conhecimentos e a natureza do ser, serão reconhecidos como dialéticos. Os que demonstraram ter natureza filosófica serão distinguidos dos demais. Aos trinta, os que perseveraram no estudo serão postos à prova, por meio da dialética, de modo a serem capazes de atingir o ser. Dialético é o indivíduo que sabe encontrar a explicação da essência de cada coisa. Serão cinco anos de estudo. Dos trinta e cinco aos cinqüenta anos, exercerão atividades militares. Após os cinqüenta anos, são finalmente conduzidos à meta, obrigados a abrir os olhos da alma e a dirigi-los para o ser que dá a luz.

O objetivo da paidéia filosófica de Sócrates e Platão não é transmitir conhecimentos, apresentar discursos rebuscados, dar respostas a todos os assuntos, habituar os indivíduos a se contentarem com respostas simplistas. Pelo contrário, o que busca essa paidéia é a periagogé, a conversão da alma, a conversão do olhar do mundo, do múltiplo, da aparência, da opinião, da ideologia, para o mundo do Uno, do Bem, da Verdade. Pela maiêutica Platão convida a todos a pensar e a viver tendo como autoridade a razão. Com a filosofia grega, o educador moderno aprende que o saber não é coisa que se distribui, se socializa, visto que ele, nunca está pronto e acabado, portanto morto. O saber é um sistema de idéias vivas, como a água fervente que não possui forma única, e sendo assim, o educador se relaciona com esse saber como o filósofo que não passa de um amigo do saber. O educador filósofo, não sendo dono do saber, a ele se dirige e provoca todos que estão à sua volta a ir com ele do fundo da caverna, do mundo das aparências, ao mundo do conhecimento verdadeiro. Mas é apenas um convite, uma provocação, nem todos estão dispostos a abandonarem sua comodidade, seus dogmas, seus preconceitos, seus conhecimentos aparentemente prontos. Vemos bem como Platão descreve os sofistas, e não só estes, mas todos os que se irritam com o poder de desinstalar, de causar vertigem, que possuem o saber racional.

\section{REFERÊNCIAS}

CHÂTELET, F. Platão. In: . História da filosofia - idéias, doutrinas: a filosofia pagã. Rio de Janeiro: Zahar Editores, 1973. p. 65-120.

GUTHRIE, W. K. C. Os sofistas. São Paulo: Paulus, 1995. 
JAEGER, W. Paidéia: a formação do homem grego. 4. ed. São Paulo: Martins Fontes, 2001.

MARROU, H.-I. História da educação na Antiguidade. São Paulo: E.P.U., 1990.

PLATÃO. Fedro. Belém: Universidade Federal do Pará, 1975. . O banquete. 2. ed. São Paulo: Abril Cultural, 1979.

. Ménon. 2. ed. Lisboa: Ediçōes Colibri, 1993.

. Apologia de Sócrates. Lisboa: Ediçōes 70, 1997.

- A República. 3. ed. Belém: EDUFPA, 2000a.

. Górgias. 4. ed. Lisboa: Edições 70, 2000b.

REALE, G. História da filosofia antiga I: das origens a Sócrates. São Paulo: Loyola, 1993a.

História da filosofia antiga II: Platão e Aristóteles. São Paulo: Loyola, 1993b.

SOARES, A. J. Dialética, educação e política: uma releitura de Platão. 2. ed. São Paulo: Cortez, 2002.

TEIXEIRA, E. F. B. A educação do homem segundo Platão. 2. ed. São Paulo: Paulus, 1999.

VAZ, H. C. L. Escritos de filosofia III: filosofia e cultura. São Paulo: Loyola, 1997.

Recebido em: 18 jan. 2007

Aceito em: 17 maio 2007 